\title{
COMMUNITY EMPOWERMENT THROUGH THE FORMATION OF THE PANEMBONGAN TOURISM MOVEMENT TOURISM IN TEMBONG VILLAGE, GARAWANGI DISTRICT, KUNINGAN REGENCY
}

\author{
Lia Muliawaty ${ }^{1}$, R. Taqwaty Firdausijah ${ }^{2}$, Mira Rosana ${ }^{3}$ and Kamal Alamsyah ${ }^{4}$ \\ 1,2,3,4 Universitas Pasundan, Bandung, Indonesia \\ ${ }^{1}$ lia.muliawaty@unpas.ac.id
}

\begin{abstract}
The presence of Bukit Panembongan nature tourism is inseparable from the surrounding community and the youth of Karang Taruna in Tembong Village who explore the potential possessed by one of the hill areas located in the Panembongan Village. Bukit Panembongan Nature Tourism which is located in Tembong Village, Garawangi District, Kuningan Regency was opened to the public on March 28, 2015. The area of land reaches 5ha but the effective land is around 3ha. Panembongan Hill natural attractions start open at 08.00 WIB until 17.00 WIB. Based on the conditions in the field can be found the following problems: the dissolution of the group of tourism activists in the Panembongan hill destination. Partners still have not sought to increase tourism service interest at the village / sub-district level by involving tourism service entrepreneurs in order to support the success of the K3 program, Partners still do not have the ability to organize funds seeking tourism activists (Kompepar) through the sale of souvenirs, the establishment of cooperatives, kiosks and so on. After the implementation team discussed with the local authorities, the activity implementation team determined the solution priority, namely the problem related to the formation of a tourism driving group, coordinating with the management of this tourism object was the result of collaboration between Perhutani KPH Kuningan with Forest Village Community Institutions (LMDH) and Tembong Village with a system of Community-Based Forest Management (PHBM), which is managed $90 \%$ by Perhutani and $10 \%$ by the Village. In connection with the problem, this activity aims to help resolve some of the problems faced by Partners as previously stated. The implementation method used in this activity is by lecturing and training. The conclusion of this activity is that the assistance provided by the Implementation Team can be understood by partners and is in accordance with the planned activities and priorities. Suggestions that can be delivered are: the formation of a tourism driving group, holding a meeting with the Ministry of Forestry and Forest Village Community Institutions (LMDH) and the Village Head to resolve the Joint Forest Management System pattern.
\end{abstract}

Keywords: Tourism Activists Group, Coordination, Tembong Village.

A. Introduction

Bukit Panembongan Nature

Tourism which is located in Tembong

Village, Garawangi District, Kuningan
Regency was opened to the public on March 28, 2015. The area of land reaches 5 ha but the effective land is around 3ha. The Panembongan Hill 
natural attractions start at 08.00 West Indonesia Time until 17.00 West Indonesia Time. The presence of the Bukit Panembongan natural tourism is inseparable from the surrounding community and youth of Karang Taruna in Tembong Village who explore the potential possessed by one of the hill areas located in the Panembongan Village. . In managing this tourist attraction is the result of collaboration between the Perhutani KPH Kuningan with Forest Village Community Institutions (LMDH) and Tembong Village with a pattern of Community Forest Management System (PHBM) managed $90 \%$ by Perhutani and $10 \%$ by the Village.

This tour presents a natural view that adds to the beauty of a really beautiful looking far to the expanse of rice fields and the atmosphere of the village and see the mountain and valley lined up on the hill panembongan coupled with the cool atmosphere of the pine forest this tourist location. Besides that, in Panembongan Hill there are two simple viewing posts made of bamboo, from this substation visitors usually make this place a favorite spot for taking photos.
In addition to being a tourist spot, this area is also intended for camping activities, because this place presents a very charming natural panorama. Partners in devotion is Adala $\mathrm{h}$ youth ynag be formed into tourism movers Group. one element of the " tourism community " that is committed to helping the government in developing the world of tourism. In its working mechanism, the community and the government have the same goals and ideals. Panembongan Hill nature tourism which is located in Tembong Village, Garawangi District, Kuningan Regency. In managing this tourist attraction is the result of collaboration between Perhutani KPH Kuningan with Forest Village Community Institutions (LMDH) and Tembong Village with the pattern of Community Forest Management System (PHBM) managed $90 \%$ by Perhutani and $10 \%$ by the Village. Based on the situation analysis of prospective PKM partners, the following problems were identified:

1. In managing this tourist attraction is the result of collaboration between Perhutani KPH Kuningan with Forest Village Community Institutions (LMDH) and Tembong 
Village with the pattern of Community Forest Management System (PHBM) which is managed $90 \%$ by Perhutani and $10 \%$ by villages not yet benefiting parties Village.

2. There is no KOMPEPAR as a motivator that has not been able to make entrepreneurs and the community develop their entrepreneurial spirit to achieve success.

3. Has not changed the perspective of tourism businesses.

4. Knowledge is lacking so guidance and training is needed for Kompepar members to become Human Resources as ready personnel, for example; conduct training in the field of improving the quality of crafts, arts and tourism business services and displays the results of coaching in promotional activities.

Partners condition that occur in the line According to Mubarak (2010) empowering the community can be interpreted as an attempt to restore or growup ability of a community to be able to do in accordance with the dignity and the dignity of those in exercising their rights and responsibilities as members of society.
In the Empowerment process approach it is more possible for the implementation of development that humanizes humans. In this view, community involvement in development is more directed to the form of participation, not in the form of mobilization. Community participation in the formulation of the program makes the community not only domiciled as consumers of the program, but also as producers because they have been involved in the process of making and formulating it, so that the community feels they have ownership of the program and have responsibility for its success and have more motivation for participation. Shucksmith, (2013) states a bottom-up approach to rural development ('driven from within', or sometimes called endogenous) based on the assumption that specific regional resources - natural, human and cultural - hold the key to its development. Whereas top-down rural development sees its main challenges as overcoming rural differences and distinctiveness through the promotion of universal technical skills and the modernization of physical infrastructure, the bottomup development sees key challenges as 
utilizing the difference through maintaining local distinctive human and environmental capacities.

The bottom-up model mainly concerns the mobilization of local resources and assets. That is, development society must be considered not as a development theory, but a development practice that emphasizes the emancipation of inappropriate institutions and every debilitating situation that leads to participation, community development must be a mechanism to attract the collective power of certain community members - consisting of men men and women, rich and poor, capable and disabled, etc. - to change in their territories. This empowerment has two directions, namely to release the shackles of poverty and underdevelopment and strengthen the position of the people in the power structure. Empowerment is a process and a goal. As a process, empowerment is a series of activities to strengthen the power or empowerment of weak grou ps in society, including individuals who experience poverty problems.

The concept of empowerment according to Friedman (1992) in this case alternative development emphasizes political primacy through the autonomy of decision making to protect the interests of the people based on personal resources, directly through participation, democracy and social learning through direct observation. According to Chambers, (1995) community empowerment is a concept of economic development that encapsulates social values. This concept reflects the new development paradigm, which is "people centered, participatory, empowering, and sustainable". Kompepar is one element of the "tourism community" that is committed to helping the government in developing the world of tourism. In its working mechanism, the community and the government have the same goals and ideals. Namely development, especially the tourism sector, based on the values of local wisdom by involving and empowering the participation of local communities. Kompepar was formed based on government regulations and policies, which in its management was carried out through the utilization of the potential of human resources, namely the people in the tourism area concerned. Therefore it is believed, that 
the people around the area (ODTW) will better understand and know the problems that exist in their own area.

Communities around ODTW will know well about the potential and other aspects that support tourism; for example the social aspects, the natural potential of the environment, history, and cultural customs of the region. The purpose of this service is the formation of a tourism driving group as a community formed from youth so that it can contribute to increasing tourist visits to the Tembong Bukit Panembongan Village. With the formation of Kompepar, we can see the participation of the local community as well as creating activities pioneered by Kompepar.

\section{B. Method of Implementation}

The audience for this dedication activity began with the Sports and Tourism Office, namely Sri's Sri as the Head of Tourism Marketing Division. Activities from June 2019 to March 2020 are carried out through the following stages:

\section{Activity Preparation}

a. Prepare a plan for operational activities carefully
In this stage before preparing a proposal, first coordinate with the team to arrange the stages of the activity to be carried out. Among them are planning certainty of the destinations targeted by activities, division of tasks for each lecturer, visiting destinations in Kuningan Regency in order to find out the problems faced by each tourist attraction , compiling proposals, determining the material to be delivered in accordance with the problems raised. dapi by destination.

b. Conduct a coordination meeting of the implementing team

In this stage the team carries out a team task distribution meeting, arranging a coordinating meeting, which is intended for the implementation of activities ranging from preparation, implementation, monitoring and evaluation, to the preparation or preparation of reports in accordance with the plans that have been set.

c. Me choose destinations of interest, namely Bukit destinations Panembongan.

The chosen destination of Bukit Panembongan is an object in the service activities based on the observations made by the team and 
based on the problems faced by the craftsmen.

d. Arrange a schedule of community service activities carried out .

\section{Implementation of Activities}

a. Team Coordination

In this activity, the chairperson was Dr. Lia Muliawaty.M.Si and members are Mrs. Dr. R. Taqwaty Firdausijah.M.Si and dra. Mira Rosana M.Pd was accompanied by expert expert Prof. Dr. H. Kamal Alamsyah.M.Si. The activity began with the coordination of the Team, the Team determined the object of service based on the agreement determining the destination to be chosen, namely the Bukit Panembongan Destination in Tembong Village, Garawangi District, Kuningan Regency.

b. Distribution of Assignments Material The division of tasks related to competencies possessed by the team.

Dr Lia Muliawaty.M.Si explained the reasons for choosing destinations and the substance of the importance of tourism tourism groups formed. To strengthen the personnel resources Dr.R.Taqwaty who provide material and associated with the influence of the environmental impact by Mira dra Rosana.M.Pd and accompanied by persons $\mathrm{s}$ umber of Public Administration expert Kamal Alam Prof.H .M.Si.

\section{Report Evaluation and \\ Compilation}

Evaluation is carried out after the activity is completed. The evaluation conducted by the team was based on the results of the interview that we gave to the village chief of Tembong. Whether the suggestions that the team has submitted have been made or there must still be sustainability of activities. After the evaluation, the team compiles a report that is the team's responsibility in carrying out the activities. For this reason, the team agreed to prepare a report.

\section{Result and Discussion}

Based on the division of tasks and scheduling of activities, the activities are carried out in accordance with the Team's agreement with the village chief of Tembong. The description of the implementation of the activity is conveyed as follows: 


\section{Determination of destination determination}

In this discussion the team leader Dr.Lia Muliawaty explained the reason for the appointment of the destination, namely that Bukit Panembongan has very beautiful nature and a very precise geographical location to be a location that is being favored by millennials or people now (instagramable). treated to a panoramic view of nature that is quite charming and natural, there is also a bamboo tower (Kolecer) which is the main attraction of this tourist attraction, visitors can capture the panorama around the tourist attractions.

This tour presents a natural view that adds to the beauty of a really beautiful looking far to the expanse of rice fields and the atmosphere of the village and see the mountain and valley lined up on the hill panembongan coupled with the cool atmosphere of the pine forest this tourist location. Besides that, in Panembongan Hill there are two simple viewing posts made of bamboo, from this substation visitors usually make this place a favorite spot for taking photos. In addition to being a tourist attraction, this area is also intended for camping activities, because this place presents a very charming natural panorama. Problems that occur where the management is still by Perhutani even though the access to the destination all the villages that build. Unbalanced business revenue sharing, which is $90 \%$ Perhutani $10 \%$ to the village, causing problems. The village did not provide a positive response to the sustainability of the destination. Meetings are often held between villages, LMDH and Perhutani but until now has not been able to find a way out. So the team has the task of finding a way out so that consultations occur between agencies that have a connection. Then selected Bukit Panembongan destination in Tembong village as a partner.

On 28 January 2020 the team revisited the partner, the village head with his counterpart. When visiting the team met the Tembong village head namely: father Suhara who explained the dissolution of the tourism driving group. So that Dr. R. Taqwaty Firdausijah's mother gave counseling about the importance of forming a tourism driving group. If the compost is already formed, it will greatly help the development of the Panumbangan Hill destination. Kompepar can 
empower youth in the village to be innovative and creative so that it can support the existence of destinations in the Tembong village environment. In this outreach the result is the village head will form a counterpart of youth with the help of the Department of Sports and Tourism and the team.

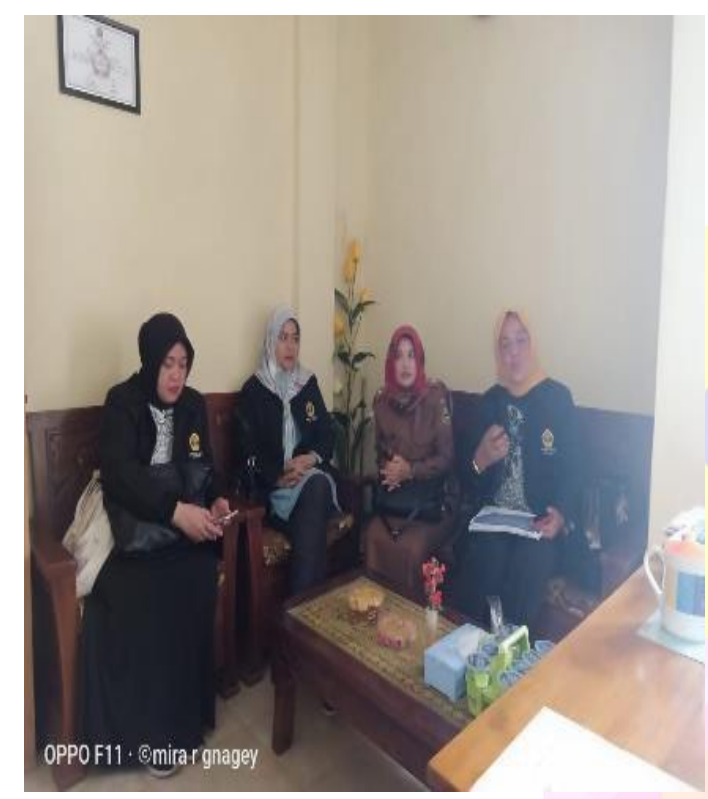

Figure 1. Counseling continued with material related to the environment.

Dra Mira Rosana gives clarity about the importance of paying attention to the environment as a picture of how the potential of villages that have a beautiful environment besides the hill panembongan. Development of destination support facilities such as souvenir shops, food and beverage stalls, and secure parking lots.

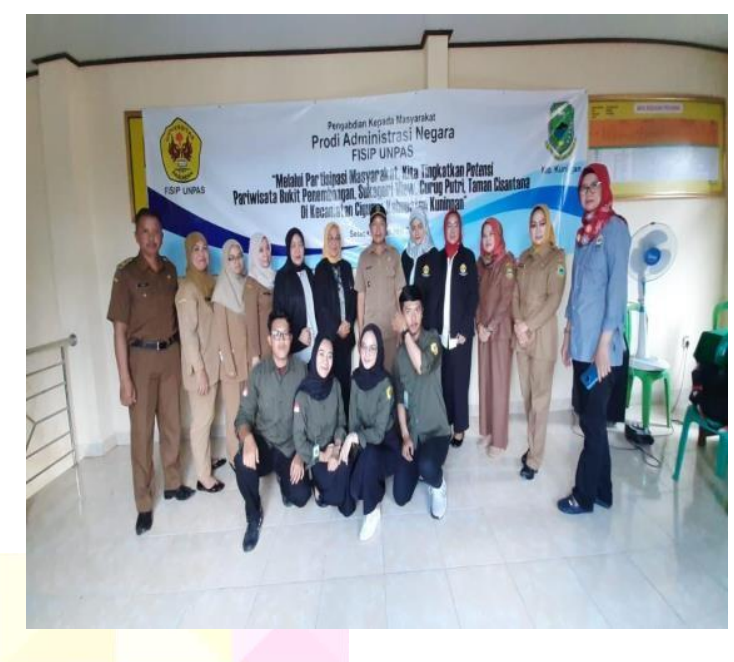

Figure 2. The final material is about

leadership activities and small business management.

This leadership activity is an activity where the partner is expected to be able to act as a leader who can overcome his subordinates or workers to become partners who can continue to work together. In addition, the village head and kompepar must be able to regulate the business activities carried out because the businesses run are small and medium businesses in which their business activities are fully carried out almost entirely by business owners.

The team got a picture of the potential that exists in the Panembongan Hill destination so the 
team had the idea that the Panembongan Hill destination in Tembong Village, Kuningan District must be ascertained first of its management. Equitable distribution of results. As well as the formation of a tourism driving group as part of the strengthening as a group that has the task of empowering the community, especially the coral reefs. How to overcome the problems faced by Partners and the Team determine the steps of the solution, as illustrated on the following page:

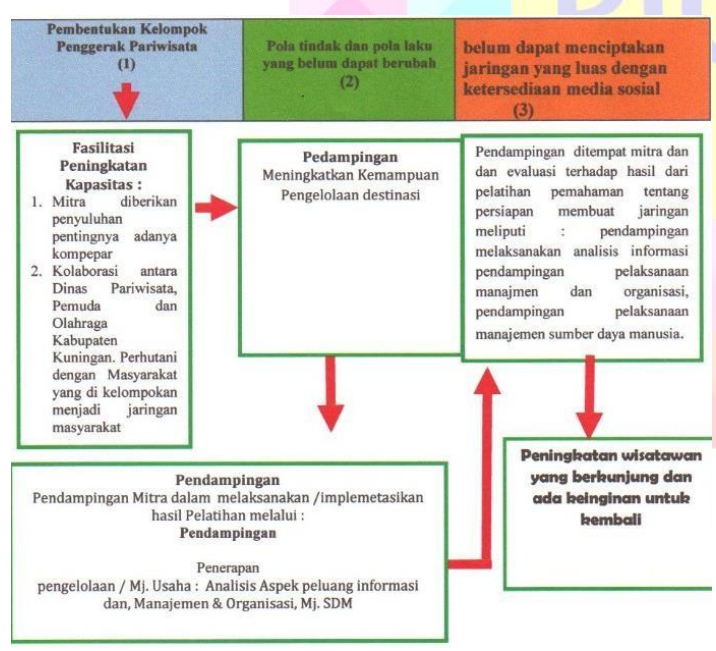

Figure 3. Step - Step Solution In

\section{Options}

\section{Conclusion}

The conclusions of the conditions aspects - the need to form a tourism driving group is as follows:

1. Increasing the participation of tourism businesses and the community in managing the services and needs of tourists in Tourism Objects and Attractions.

2. Difficult to increase the amount of tourist traffic.

3. Creating a sense of security and comfort for tourists who have a will.

4. Not yet increased Tourism Awareness for the community around the Objects and Attraction.

5. Utilize and increase the potential of tourism objects and improve the quality of services for tourists.

6. Advice : a. Formation of tourism driving groups; b. Hold a discussion between Perhutani, LMDH, and the Village regarding ownership management and business results; c. There is a tourism information center; and d. Sustainability of the program even if the leadership changes.

\section{REFERENCES}

Friedman, John. 1992. Empowerment The Politics of Alternative Development . Blackwell Publishers, Cambridge, USA.

Glasserfield, E. (1987). A Constructivist Approach to Teaching. In L. Steffe \& J. Gale (Eds.), 
Constructivism in Education

Hillsdale, NJ, Lawrence Erlbaum. (pp. 3-16).

Ife, JW 1995. Community Development: Creating Community Alternatives-vision, Analysiis and Practice . Melbourne: Longman.

Jasper, James M. 2010. Social Movement Theory Today: Toward a Theory of Action ?. Sociology Compass 4/11 (2010): pp., 965-976, 10.1111 / j.9020.2010.000329.x, .New York: Graduate Center of the City University of New York.

Jimu, MI 2008. Community Development . Community Development: A CrossExamination of Theory and Practice Using Experiences in Rural Malawi. Africa Development, Vol. XXXIII, No. 2, 2008, pp. 23-3.

Koentjaraningrat. 2009: Human and Culture in Indonesia. Djambangan. Jakarta. Longm. Lubis, Hari \& Huseini,

Martani. 1987. Organizational Theory; A Macro Approach . Center for Interdisciplinary Social Sciences UI: Jakarta.

Mubarak, Z. 2010. Evaluation of Community Empowerment Based on the Capacity Building Process of the PNPM Urban Urban Program in the Sastrodirjan Village, Pekalongan

Regency. Thesis . Master Program in Urban and Regional Empowermen Engineering. Undip. Semarang. 